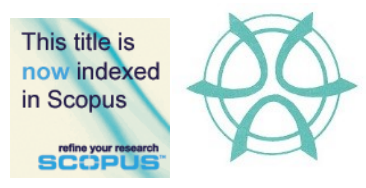

\title{
THE CONSIDERATION OF ZONING COMPLIANCE ON THE IMPLEMENTATION OF THE FASTRACK NIL IN JOHOR
}

\author{
Amirul Haffiz Ariff ${ }^{1}$, Suhailizan Suliman², Mohd Shahrizan Sahid ${ }^{3}$, \\ Muhaymin Hakim Abdullah ${ }^{4}$ \\ ${ }^{1,2,3}$ Department of Real Estate, Faculty of Built Environment and Surveying \\ UNIVERSITI TEKNOLOGI MALAYSIA, MALAYSIA \\ ${ }^{4}$ Jabatan Sains Sosial, Pusat Pengajian Umum dan Kokurikulum \\ UNIVERSITI TUN HUSSIN ONN
}

\begin{abstract}
Under Section 53 of National Land Code 1965, there were lands alienated before the commencement of NLC whereby the titles do not indicate any particular category of land use and express conditions, but instead are stated as 'Nil'. Therefore, this paper aims to describe the procedure of Fastrack NIL implementation in Johor and its consideration of zoning compliance upon the imposition of land categories and express conditions for land stated as 'Nil'. Using content analysis and interview with selected respondent using purposive sampling, it is confirmed that the imposition of conditions or land conversion does not need to be in accordance with the zoning compliance. However, this practice is becoming a norm due to the equitable interests held by landowners and taking into account the interest of the state government, thus zoning must be considered in the Fastrack NIL application.
\end{abstract}

Keywords: Zoning, land category, express condition, quit rent

\footnotetext{
${ }^{1}$ Phd Candidate Email: ahaffiz81@gmail.com
} 
PLANNING MALAYSIA

Journal of the Malaysia Institute of Planners (2021)

\section{INTRODUCTION}

The economic value or potentiality of a land depends on the land use properties (Burton et al., 2004). According to the main legislation that governs land throughout the states in Peninsular Malaysia, National Land Code 1965 (NLC), the land use property laid under Section 52 and Section 120. Pursuant to Section 52 , the code prescribed that the land use category can be classified into three categories namely agriculture, building and industrial. While Section 120 of the code prescribes the imposition of express conditions and restrictions in interests determined by the State Authority at the time when the land is approved for alienation. The determination of land categories and express conditions is significant to control land use so that it is aligned with the planning aspect of the local development plan and taking into account the interest of the State Authority. Additionally, land use property is also stated under the Town and Country Planning Act 1976 (Act 172). According to Section 12, land use property referred to as zoning is used to divide land under the statutory area of local authority into sections, permitting particular land uses on specific sites to shape the layout of towns and cities, thus enabling various developments to take place (The World Bank, 2015). Similarly, zoning works as a planning tool to regulate the built environment and create functional real estate markets, it also ensures complementary uses as well as stimulate development in specific areas (McDonald, 1997; Bogart, 1998).

\section{RESEARCH BACKGROUND}

Under Section 53 of NLC, there were lands alienated before the commencement of NLC whereby the titles do not indicate any particular category of land use and express conditions, but instead are stated as 'Nil'. These were the lands which had been alienated before the commencement of the NLC. According to the Jabatan Ketua Pengarah Tanah dan Galian Persekutuan (2002), during that time there was no specific provision under the previous land law that allows the imposition of land use categories as currently available, namely agriculture, building and industry. Besides, the town or village zoning plan remains unclear (Lee, 2020). The alienation of these lands under the land law before the enactment of NLC only classified these lands into two (2) types, namely Town Land or Village Land; and Country Land. The State Authority at that time had the liberty to impose any express conditions in land use as they think fit (Awang, 1997).

Although this type of land is valuable since the owner can use it for any purpose or a combination of purposes, the quit rent amount charged on these lands may be even higher than the market value. In Pahang, Pahang Land (Amendment) (No. 4) Rules 2019 stated that lands with no category and specific conditions shall be charged two times, the highest rate of rent payable in the state (Lee, 2020). Similarly, this type of land has also experienced a spike in quit rent in Johor ever since the JPU 49 was gazetted and a new rate of quit rent was enforced on 1st 
Amirul Haffiz Ariff, Suhailizan Suliman, Mohd Shahrizan Sahid, Muhaymin Hakim Abdullah

The Consideration of Zoning Compliance on The Implementation of The Fastrack Nil in Johor

January 2020. As illustrated in Table 1 below, the new quit rent under JPU 49 is charged according to the land use condition for 'A Class Urban Land' plus $40 \%$ additional rate charged according to the land use category, i.e., agriculture, building, or industry. Consequently, Pavither (2020) highlighted that the quit rent is found to have increased significantly, for instance, in Kluang (from RM90 to RM750), Tangkak (from RM7 to RM150), Johor Bahru (from RM100 to RM1,000), and Tebrau (RM5,275 to RM21,000).

Table 1: The difference of quit rent rate between JPU 95 and JPU 49 for the land under

\begin{tabular}{|c|c|c|c|c|}
\hline \multicolumn{5}{|c|}{ Section 53 of NLC } \\
\hline \multirow{2}{*}{ Types } & \multicolumn{2}{|c|}{ JPU 95} & \multicolumn{2}{|c|}{ JPU 49} \\
\hline & Rate (RM) & Calculation & Rate (RM) & Calculation \\
\hline \multicolumn{5}{|c|}{ Category: Agriculture } \\
\hline $\begin{array}{l}\text { Conditions } \\
\text { NIL }\end{array}$ & $\begin{array}{l}\text { No stipulation } \\
\text { under JPU 95 } \\
\text { Revision from } \\
\text { Johor Land and } \\
\text { Mine: } \\
\text { - Vacant land - } \\
\text { RM150/hectare } \\
\text { - Developed land } \\
\text { - rate based on } \\
\text { land use } \\
\text { condition / } \\
\text { building on land } \\
\text { (according to the } \\
\text { Site Officer } \\
\text { report) }\end{array}$ & $\begin{array}{l}\text { Vacant land } \\
\text { Sample area: } \\
0.14540 \text { hectare } \\
0.1454 \text { hectare }<1 \\
\text { hectare }= \\
\underline{\text { RM150.00 }}\end{array}$ & $\begin{array}{l}\text { RM250/hectare or } \\
\text { part of it }\end{array}$ & $\begin{array}{l}\text { Vacant land } \\
\text { Sample area: } \\
0.14540 \text { hectare } \\
0.14540 \text { hectare }<1 \\
\text { hectare }= \\
\underline{\text { RM250.00 }}\end{array}$ \\
\hline
\end{tabular}

\begin{tabular}{|c|c|c|c|c|}
\hline \multicolumn{5}{|c|}{ Category: Building } \\
\hline $\begin{array}{l}\text { Conditions } \\
\text { NIL }\end{array}$ & $\begin{array}{l}\text { No stipulation } \\
\text { under JPU } 95 \\
\text { Revision from } \\
\text { Johor Land and } \\
\text { Mine: } \\
\text { - Developed land - } \\
\text { rate based on land } \\
\text { use condition / } \\
\text { building on land } \\
\text { (according to the } \\
\text { Site Officer } \\
\text { report) }\end{array}$ & $\begin{array}{l}\text { Residential: } \\
\text { A Land Category } \\
\text { Sample area: } \\
\text { 1570.34 square } \\
\text { meters } \\
=16 \text { (rounded) x } \\
\text { RM21 } \\
=\underline{\text { RM336.00 }}\end{array}$ & $\begin{array}{l}\text { The rate of quit rent } \\
\text { is according to the } \\
\text { land use category } \\
\text { for 'A Class Urban } \\
\text { Land' plus } 40 \% \\
\text { additional rate } \\
\text { charged according } \\
\text { to the land category }\end{array}$ & $\begin{array}{l}\text { Residential: } \\
\text { A Land Category } \\
\text { Sample area: } \\
1570.34 \text { square } \\
\text { meters } \\
=16 \text { (rounded) x } \\
\text { RM30 x 40\% } \\
=16 \times \text { RM42.00 } \\
=\underline{\text { RM672.00 }}\end{array}$ \\
\hline
\end{tabular}

\begin{tabular}{lllll}
\hline \multicolumn{2}{l}{ Category: Industry } & & & \\
\hline Conditions & No stipulation & Heavy Industry: & *RM3,000.00 for & Sample area: \\
NIL & under JPU 95 & A Land Category & area less than 5,000 & 3,242 square meters \\
& & Sample area: & square meters & $3,242 \mathrm{~m}^{2}<5,000$ \\
& & 0.3242 hectare & & $\mathrm{m}^{2}$ \\
\hline
\end{tabular}


PLANNING MALAYSIA

Journal of the Malaysia Institute of Planners (2021)

\begin{tabular}{|c|c|c|c|c|}
\hline & $\begin{array}{l}\text { Revision from } \\
\text { Johor Land and } \\
\text { Mine: } \\
\text { - Developed land - } \\
\text { rate based on land } \\
\text { use condition } \\
\text { whether heavy, } \\
\text { medium or light } \\
\text { industry } \\
\text { (according to the } \\
\text { Site Officer } \\
\text { report) }\end{array}$ & 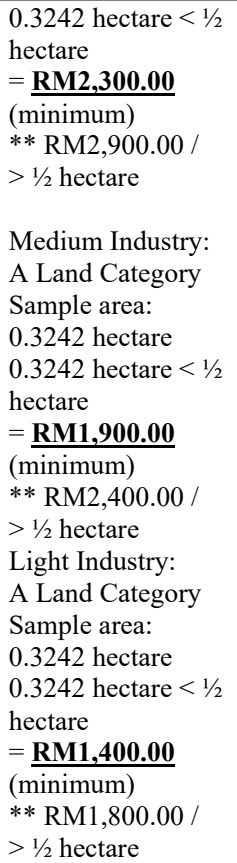 & $\begin{array}{l}* \text { RM5,000.00 for } \\
\text { area more than } \\
5,000 \text { square meters } \\
\text { but less than } 10,000 \\
\text { square meters } \\
\text { *RM50.00 for each } \\
\text { square meter for } \\
\text { area more than } \\
10,000 \text { square } \\
\text { meters or part of it }\end{array}$ & $\begin{array}{l}=\underline{\mathbf{R M 3 , 0 0 0 . 0 0}} \\
\text { Sample area: } \\
9,635 \text { square meters } \\
5,000 \mathrm{~m}^{2}>9,635< \\
10,000 \mathrm{~m}^{2} \\
=\underline{\mathbf{R M 5}, \mathbf{0 0 0 . 0 0}} \\
\text { Sample area: } \\
\text { 23,342 square } \\
\text { meters } \\
\text { 23,342 square } \\
\text { meters }>10,000 \mathrm{~m}^{2} \\
=234 \text { (rounded) } \mathrm{x} \\
\text { RM50 } \\
=\underline{\mathbf{R M 1 1 , 7 0 0 . 0 0}}\end{array}$ \\
\hline \multicolumn{5}{|c|}{ Category: No land use and express conditions } \\
\hline $\begin{array}{l}\text { No land } \\
\text { use and } \\
\text { express } \\
\text { conditions }\end{array}$ & $\begin{array}{l}\text { No stipulation } \\
\text { under JPU 95 } \\
\text { Revision from } \\
\text { Johor Land and } \\
\text { Mine: } \\
\text { - Developed land } \\
\text { - rate based on } \\
\text { land use } \\
\text { condition / } \\
\text { building on land } \\
\text { (according to the } \\
\text { Site Officer } \\
\text { report) }\end{array}$ & $\begin{array}{l}\text { Rate is based on the } \\
\text { calculation above } \\
\text { according to the } \\
\text { related land use } \\
\text { category }\end{array}$ & $\begin{array}{l}\text { The rate of quit rent } \\
\text { is according to the } \\
\text { land use category } \\
\text { for 'A Class Urban } \\
\text { Land' plus } 40 \% \\
\text { additional rate } \\
\text { charged according } \\
\text { to the land category }\end{array}$ & $\begin{array}{l}\text { Agriculture: } \\
\text { Use for orchard } \\
\text { Sample area } 2.72 \\
\text { hectare } \\
2.72 \text { hectare }<4 \\
\text { hectare } \\
=3.0 \text { (rounded) } \mathrm{x} \\
\text { RM42.00 } \\
=\underline{\text { RM126.00 }} \\
\text { Building: } \\
\text { Residential: A Land } \\
\text { Category } \\
\text { Sample area: } \\
1570.34 \text { m } \\
=16 \text { (rounded) } x \\
\text { RM30 x } 40 \% \\
=16 \times \text { RM42.00 } \\
=\underline{\text { RM672.00 }}\end{array}$ \\
\hline & & & & $\begin{array}{l}\text { Industry: A Land } \\
\text { Category } \\
\text { Sample area: } \\
23,342 \mathrm{~m}^{2} \\
23,342 \mathrm{~m}^{2}>10,000 \\
\mathrm{~m}^{2}\end{array}$ \\
\hline
\end{tabular}


Amirul Haffiz Ariff, Suhailizan Suliman, Mohd Shahrizan Sahid, Muhaymin Hakim Abdullah

The Consideration of Zoning Compliance on The Implementation of The Fastrack Nil in Johor

$=234$ (rounded) $\mathrm{x}$

RM49

$=\underline{\mathbf{R M 1 1}}, \mathbf{4 6 6 . 0 0}$

To rectify the situation, Johor Land Administration initiated Fastrack NIL campaign to address the issue. The initiative aimed to encourage landowners to apply for the imposition of land categories and express conditions to align the actual and ongoing development on the land or development as gazetted in local plan. This initiative will assist to parallel the amount of quit rent imposed on the land to the current market value. However, conflict of zoning may arise if the landowner decides to apply through Fastrack NIL. Therefore, this paper aims to describe the procedure of Fastrack NIL implementation in Johor and its consideration of zoning compliance upon the imposition of land categories and express conditions for such land.

\section{THE IMPOSITION OF LAND USE CATEGORIES AND CONDITIONS FOR THE LAND UNDER SECTION 53 OF NATIONAL LAND CODE 1965}

Before or after the commencement of NLC, land alienated by the State Authority must be categorised under one of the three categories whether agricultural land, building land or industrial land. Before NLC was enacted on 1st January 1966, there was no specific provision under the previous land law that recognised the imposition of land use categories as the one currently available under Section 52 of the code (Awang, 1997; Jabatan Ketua Pengarah Tanah dan Galian Persekutuan, 2002). Besides, the town or village zoning plan during that time remains unclear (Lee, 2020). As mentioned by Awang (1997), the land use category before the commencement of NLC is restricted to the type of use such as 'padi', 'dusun', 'jetty', 'factory', or NIL. The alienation of these lands under the land law before the enactment of NLC only classified these lands into two (2) types, namely (i) Town Land or Village Land; and (ii) Country Land. The State Authority at that time had the liberty to impose any express conditions in land use as they think fit (Jabatan Ketua Pengarah Tanah dan Galian Persekutuan, 2002).

However, when NLC came into force in 1966, Section 53 was automatically imposed on all country, town, and village lands held under the Land Office Title, subjected to implied conditions for agricultural purposes only. While Section 53(3) provides that any country and town land registered under Registry Title with a category neither being agriculture nor industrial are subjected to the use for the purpose of building only. Nevertheless, this provision does not prevent the landowner to utilise his land for the purpose of agriculture, building, or industry which had long been operating legally prior to the enactment of NLC. 
According to Awang (1997), the category imposed on a piece of land does not come with guidelines to tell the landowner on how to utilise the land legally. Thus, this shortcoming of Section 52 must be complemented with imposition of conditions as a mechanism to guide landowners. Awang (1997) further explained that the endorsement of express conditions as well as the automatic application of implied condition as stated under Section 115 (for agricultural land), Section 116 (for building land) and Section 117 (for industrial land) will then guide the owner. For instance, his agricultural land can only be cultivated for the purpose of growing a specific crop for e.g., oil palm, pineapple, cocoa, or etc. Therefore, express conditions and categories of land exist to complement and strengthen each other.

However, the interests for every land under the demarcated administrative boundary held by the State Authority are broad. Thus, restrictions in interest give more room to the State Authority to exercise its power within the range of its discretionary limits. Restriction in interest will allow the State Authority to endorse specific terms on the land to meet the special needs or interests of the state (Awang, 1997). In Johor, the restriction of interests can be found in the statement such as 'the land could not be transferred to non-bumi unless approved by the State Authority'.

The power to impose express conditions and restriction in interest by the State Authority is held under Section 120 of NLC. Both terms 'condition' and 'restrictions in interest' that usually appear together in the NLC bear different meanings and thus hold different legal implications. According to Section 5 of NLC, 'restriction in interests' is defined as any limitation imposed by the State Authority on any of the powers conferred on a proprietor by Part IX, or on any of his powers of dealing under Division IV, and any like limitation imposed under any previous land law. While 'condition' is referred to as anything that does not include any restriction in interests (Section 5) or any express or implied condition in any agreement in which the State Authority is not a party (Section 103).

From the definition, both terms can be distinguished clearly whereby restriction in interests is referred to as any limitation imposed by the State Authority on the power of the registered land proprietor on his land to subdivide, partition, or amalgamate as well as the limitation on his power to deal with it by way of transfer or the creation of a lease, charge, easement, tenancy, statutory lien. While condition is more related to the manner to which the land is to be utilised by the landowner. For example, the State Authority may impose express conditions on agricultural land requiring the cultivation of specific crops. These conditions and restriction in interests are imposed by the State Authority at the time when the land is approved for alienation and must be endorsed on or referred to in the document of title.

The discretion of the State Authority to impose express condition and restriction in interests in respect of alienated land is not controlled in regard to 
Amirul Haffiz Ariff, Suhailizan Suliman, Mohd Shahrizan Sahid, Muhaymin Hakim Abdullah

The Consideration of Zoning Compliance on The Implementation of The Fastrack Nil in Johor

initial alienation. The imposition is only driven by political or socio-economic considerations. As provided under Section 120(1), the State Authority may alienate land under this Act subject to such express conditions and restrictions in interests conformable to law as it may think fit.

However, the imposition must be conformable to any written law in force. Thus, whenever the State Authority acts in accordance with its discretion to impose conditions or restriction in interests on the land as described under Section 53, does the imposition of land categories and express conditions for the land require zoning consideration? Since Section 120 of the NLC recognise the power of the State Authority to impose land use categories and conditions, among others to control land use and coordinated it with the planning aspect without disregarding the interests of the state government, does it require State Authority to comply with the planning term under the provisions of Town and Country Planning Act (Act 172)? These questions are somehow responded to by the provision as laid under Section 108 of the NLC provides that 'conditions attached to the land title shall prevail over planning restrictions. This question is further analysed and detailed in the subsequent section.

\section{METHODOLOGY}

To address the key objective, this study employed a qualitative research method. Data primer consists of a series of in-depth interviews that were conducted with Johor Land Administration Officer to study the process of the imposition of land use categories and conditions for the land in question under Section 53 through the Fastrack NIL campaign. Using purposive sampling, four respondents from the Johor Bahru Land Office (PTJB) and Office of the Director of Land and Mines Johor (PTG Johor) were selected. These officers have direct involvement with this campaign from the proposal stage until its approval by the Majlis Mesyuarat Kerajaan Johor on 11 September 2019, as well as its implementation. Besides, years of service is one of the eligibility indicators of the respondents to be part of this research. The list of the selected respondents is briefly shown in Table 1 below.

Table 1: List of respondents involved in this study

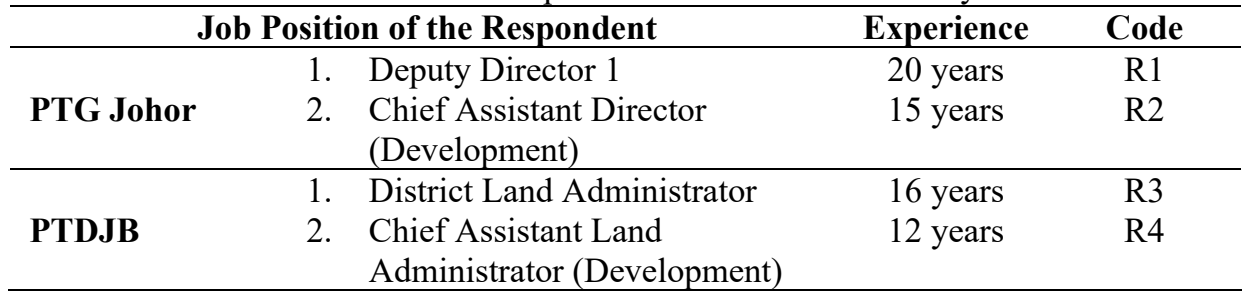


To support the primary data, secondary data is retrieved from various articles, government documents, books, related circulars, and the National Land Code 1965 to strengthen the analysis. All the data gathered were then analysed descriptively.

\section{RESEARCH FINDINGS AND DISCUSSIONS}

\section{Fastrack Nil Initiative in Johor Land Administration}

According to R1 and R3, initially Fastrack NIL was introduced by Johor Land Administration due to the restructuring of the new rate of quit rent enforced on 5th December 2019 and subsequently gazetted by JPU 49 on 1st January 2020. Within the first five days of the enforcement, Johor Land Administration has received numerous feedbacks from the landowners as well as among the community leaders regarding the new rate of quit rent especially for land stated as 'NIL' that increased dramatically compared to the previous rate before the restructuring.

To address the issue, Johor Land Administration has taken an approach in initiating a special campaign to encourage landowners with land stated as 'NIL' to apply for the imposition of conditions in accordance to the actual land use and category on the land whether agricultural, building, or industrial and thus restructuring the amount of quit rent imposed on the land to the current market value. On 11th September 2019, Majlis Mesyuarat Kerajaan Negeri Johor has agreed to apply the 'Approval Over Submission (AOS)' initiative for application to impose conditions, land conversion, or application for additional conditions from 'Nil', agriculture (nil) to agriculture (tree) within one (1) working day. Thus, the imposition of express conditions from nil to building (residential or commercial) or industrial through the fast-track process is another additional initiative to the AOS.

From the interviews, all respondents R1, R2, R3, and R4 agreed that Fastrack NIL is an initiative for the landowner (with land stated as 'NIL') to apply for the imposition of conditions from NIL to the actual category on land whether residential building, commercial building, industry, or agriculture (tree). Currently, the application to impose conditions from none to other conditions based on the land use category set by NLC will be submitted to the District Land Office where the application will be referred to obtain reviews from the department or technical agency as well as internal review by the Assistant Land Officer. However, some of the reviews from the department or technical agency were delayed and caused the process to impose conditions or land conversion taking longer time for approval. The application will then be raised for the consideration of the Jawatankuasa Hasil Bumi, which will then be brought to the Majlis Mesyuarat Kerajaan Johor for approval. This process is simplified as illustrated in Figure 1. 
Amirul Haffiz Ariff, Suhailizan Suliman, Mohd Shahrizan Sahid, Muhaymin Hakim Abdullah

The Consideration of Zoning Compliance on The Implementation of The Fastrack Nil in Johor

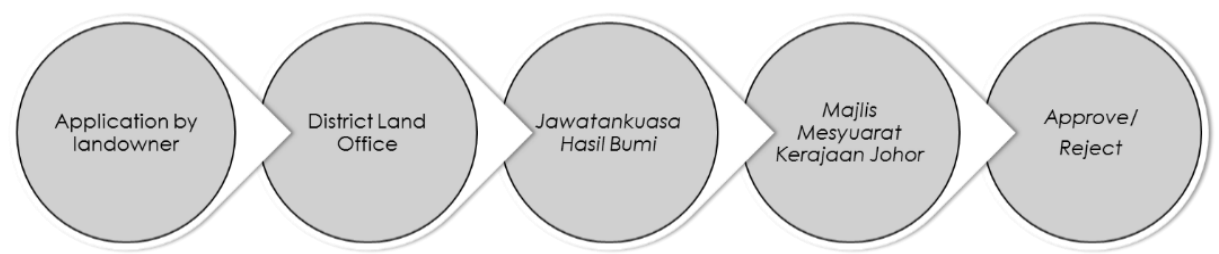

Figure 1: The application process to impose conditions from none to other conditions based on the land use category set by NLC

As a result of the quit rent restructuring, the imposition of land category and conditions on the land in question must be done immediately so that the actual quit rent can be applied. Thus, the current approach in processing the application required modification to expedite the process. The trial period of Fastrack NIL implementation through a special campaign lasted for three months, from $1 \mathrm{st}$ January to 31st March 2020 and the Director of Land and Mines Johor is allowed to extend the period as where it seems appropriate.

Respondent R1, R2, R3, and R4 have ensured that they are four main benefits offered by Fastrack NIL initiative to landowners. They are:

i. Landowners can submit the application to impose conditions directly by themselves to the District Land Administrator without appointing a licensed surveyor to apply on their behalf. Thus, the application cost bear by the landowner can be minimized greatly;

ii. The application will be processed within seven working days compared to the current process in practice that takes a longer time to approve;

iii. Landowners can proceed for the application without having to pay the current quit rent according to the NLC provision under Section 124 of the code; and

iv. Landowners with land stated as 'NIL' are not required to pay a higher amount of quit rent once the application is approved.

\section{The Consideration of Zoning Compliance in Fastrack Nil Application Process}

Based on the interviews conducted with respondent R3 and R4 from PTJB, Fastrack NIL application from nil to building residential, commercial or industrial can be initiated when application is submitted to the District Land Office (PTD) is completed together with the fee (RM200 for residential, RM1000 for commercial and industrial) and related documents required. The application received by PTD does not require any reference to other technical departments where any conditions or requirements of the technical department will only be imposed when a development plan such as Pelan Bangunan (PB) or Kebenaran Merancang Pendirian (KMP) is submitted to Local Planning Authority (PBPT). 
Respondents R3 and R4 have a similar point of view, they think the application to impose conditions or land conversion does not require planning consideration. The provision under Section 124 of NLC and Section 2 of Act 172 has clearly stated that the imposition of condition or land conversion is not a form of development that requires planning input. Respondent R3 further explained that planning input can simply be referred to as compliance to the zoning. Legally, the imposition of conditions or land conversion according to Section 124 of NLC cross reference with Section 2 of Act 172 does not need to be in accordance with the zoning. However, this practice is becoming a norm due to the equitable interests hold by landowners and taking into account the interest of the state, thus zoning in the local development plan must be considered in the Fastrack NIL application. Therefore, application submitted must include certified zoning on the site applied from the PLANMalaysia Johor or a local authority, in addition to the documents showing the applicants confirmation of the building located on the site through a statutory declaration letter (for the individual landowners) together with company resolution certified by the company secretary for a company's application.

At this stage, the landowner is allowed to submit an application without having to pay the current quit rent as a requirement to give room for the landowner to be charged with the amount according to the actual land conditions. However, the current quit rent (new rate) must be paid together with other payment in Form 7G. The application of Fastrack NIL for residential building, commercial, and industrial is done through the power of approval given to the District Land Administrator or Small District Land Administrator regardless of Land Office Title or Registry Title. A complete application will be processed and a result notification with $7 \mathrm{G}$ Notice will be issued within seven working days from the date of the application received. Respondent R4 added, in accordance with the Fastrack NIL implementation, the approved application will be charged as a premium as per JPU 94 Schedule VII of the Johor Land Rules where the premium together with other approval fees must be paid within 30 days from the date of Notice 7G. This process will be done similarly to the Fastrack NIL for commercial and industrial.

\section{CONCLUSION}

The implementation of Fastrack NIL is an approach to encourage any land that is still subject to use under Section 53 of NLC, namely lands that were alienated before the commencement of NLC to be subjected to land categories and conditions in accordance with the provisions of Section 52 of the code whether it is agricultural, building (residential or commercial), or industrial category. The implementation of this initiative is in line with one of the intentions of Johor Land Administration and Section 124 whereby landowners can submit the application for the consideration of State Authority to impose land category and conditions 
Amirul Haffiz Ariff, Suhailizan Suliman, Mohd Shahrizan Sahid, Muhaymin Hakim Abdullah

The Consideration of Zoning Compliance on The Implementation of The Fastrack Nil in Johor

based on the actual development on land so that the quit rent charge is a reasonable amount. The main catch is the approval will be given within 7 days only from the date of a complete application is received. This approach is to show the commitment and continuous efforts of the Johor Land Administration in improving the level of service delivery in land matters and to achieve the utmost level of customer satisfaction, especially among landowners who contribute to the revenue of the State Authority.

\section{ACKNOWLEDGEMENTS}

The authors are grateful to the State Government of Johor, Universiti Teknologi Malaysia, anonymous reviewer and other contributors to the paper. This study is indebted to all agencies involved in providing data and information required.

\section{REFERENCES}

Awang, A. (1997) 'Land conversion, subdivision and amalgamation', Universiti Teknologi Malaysia.

Bogart, W. T. (1998) The economics of cities and suburbs. Pearson College Division.

Burton, R. M., Lauridsen, J. and Obel, B. (2004) 'The impact of organizational climate and strategic fit on firm performance', Human Resource Management: Published in Cooperation with the School of Business Administration, The University of Michigan and in alliance with the Society of Human Resources Management, 43(1), pp. 67-82.

Jabatan Ketua Pengarah Tanah dan Galian Persekutuan (2002) 'Ketua Pengarah Tanah Dan Galian Persekutuan Circular No. 1/2002', (2). Lee, L. (2020) BACK TO BASIC - WHAT INFORMATION CAN YOU GATHER FROM A LAND TITLE?

McDonald, J. F. (1997) Fundamentals of urban economics. Prentice Hall.

Pavither (2020) Fast Track NIL Initiative to Address Spike in Quit Rent, Property Guru. The World Bank (2015) Zoning and Land Use Planning.

Received: $19^{\text {th }}$ August 2021. Accepted: $10^{\text {th }}$ November 2021 